\title{
PRELIMINARY RISK ANALYSIS OF LOW PRESSURE RAILWAY TRANSPORT
}

\section{Wstępna analiza ryzyka podróży koleją niskociśnieniową}

\begin{abstract}
The subject of this study is a preliminary risk analysis during travel by the low pressure railway Hyperloop. The main objective was to formulate recommendations related to the development of the project of the new transport mode. The main analysis was preceded by the identification of Man - Machine - Environment system. Undesirable events were identified for each of the specified steps of a ride. For each event, a risk assessment was performed using Risk Score based method. The causes, effects and preventive actions were also listed. Events with the highest risk score were indicated. The need to develop procedures for safety checks and emergency situations was pointed out. It was shown that the safety analysis of the transport system should be extended after a final project development of the railway system and the necessary infrastructure.
\end{abstract}

Keywords: transport, safety, low pressure railway, Hyperloop, risk analysis, Risk Score method

Streszczenie: Tematem niniejszej publikacji jest wstępna analiza ryzyka podczas podróży koleja niskociśnieniowa Hyperloop. Głównym celem byto sformułowanie zaleceń zwiąanych z rozwojem projektu nowego środka transportu. Właściwa analize poprzedzono identyfikacja systemu człowiek - technika - otoczenie, zidentyfikowano zdarzenia niepożądane dla każdego z wyszczególnionych etapów podróży. Dla każdego zdarzenia dokonano oceny ryzyka z wykorzystaniem metody zbliżonej do Risk Score. Wyszczególniono także przyczyny, skutki oraz działania zapobiegawcze. Wskazano zdarzenia o najwyższym wskaźniku ryzyka. Zwrócono uwage na konieczność opracowania procedur dotyczacych kontroli bezpieczeństwa oraz wystapienia sytuacji awaryjnych. Wykazano, ̇̇e analiza bezpieczeństwa omawianego systemu transportowego powinna być rozszerzona po opracowaniu szczegółowego projektu kolei i niezbędnej infrastruktury.

Słowa kluczowe: transport, bezpieczeństwo, kolej niskociśnieniowa, Hyperloop, analiza ryzyka, metoda Risk Score 


\section{Introduction}

Safety activities concern many aspects of man life and his functioning in the ManMachine-Environment (M-M-E) system. The development of safety science is related to the ability of better hazard identification, considering safety issues at the stage of designing technical devices and progress in counteracting threats by developing existing and proposing new methods of risk and reliability analysis [12].

One system whose concepts are being developed around the world is the "Hyperloop". It is a mode of transport that can be classified between the aircraft and the train. It involves travelling at very high speed in a special prepared capsule inside a reduced pressure tunnel [10]. Although the concept of passing a vehicle inside a tube with reduced pressure has been considered for years, the author of the name and assumptions of the "Hyperloop" vehicle is the American entrepreneur and multi-billionaire Elon Musk. According to his idea, the vehicle is supposed to be, compared to other means of transport, safer, faster, cheaper, more comfortable, resistant to weather conditions and earthquakes, sustainable in terms of energy and collision-free [8]. It should be noted that in some countries - the USA and South Korea - studies and works are so advanced that test runs are already taking place. In Korea, test runs without passengers were conducted at speeds of about 700 and $1000 \mathrm{~km} / \mathrm{h} \mathrm{[13].} \mathrm{In} \mathrm{the}$ USA, a test ride with two passengers was carried out on a 500 meters test track at a speed of $160 \mathrm{~km} / \mathrm{h}$, there was also a series of test runs at approx. $400 \mathrm{~km} / \mathrm{h}$ without passengers. Ultimately, it is planned to exceed $1000 \mathrm{~km} / \mathrm{h}$ over a longer distance [14]. In Poland tests have taken place in a mechanical and virtual low pressure railway simulator [15]. A description of the main principles of operation of the low-pressure railway of which the simulator was built can be found in the study [9].

In all projects about this new mode of transport, safety analyses play an important role. Due to the lack of relevant standards and regulations in this field, it is necessary to refer to universal standards for the safety of technical equipment [16], as well as regulations [17, 18] and standards (e.g. [19]) related to traditional railway. Normative acts on the principles of conducting safety checks in air transport [20,21] may be useful, a possibility of using lightweight materials used in aviation should be considered. Original concepts and solutions related to risk analysis and management in transport $[6,11]$ are also important. Attempts are made to develop appropriate recommendations related to the "Hyperloop" technology also in the context of safety system management. It is realized on the basis of risk analyses with the use of: detailed description and assessment of individual properties, characteristics and components of the transport system [5], risk maps and SWIFT (Structured What If Technique) method [7], HAZOP (Hazard and Operability Study) based model [2]. In ongoing research, comparisons and references to existing transport systems can often be found. Issues related to the potential for technological development and commercialization of investments [4] and public acceptance of the new transport mode [1] are also considered.

The risk analysis to be carried out in this paper will address aspects related to the safety of use and ergonomics of the low pressure rail system using a qualitative indicator (scoring) 
method similar to Risk Score [3, 12]. The economic or social issues associated with implementing the low pressure rail system will not be studied.

\section{M-M-E system identification}

Before starting the identification of hazards and searching for possible undesirable events, it will be important to identify the analyzed Man - Machine - Environment (M-ME) system. The identification of individual system segments is presented in table 1 .

Table 1

M-M-E system identification

\begin{tabular}{|c|c|c|}
\hline Man & Machine & Environment \\
\hline $\begin{array}{l}\text { - low pressure rail } \\
\text { passengers; } \\
\text { persons responsible for } \\
\text { the management of rail } \\
\text { traffic; } \\
\text { other staff of railway and } \\
\text { station. }\end{array}$ & $\begin{array}{l}\text { - } \text { "Hyperloop" low } \\
\text { pressure railway } \\
\text { consisting of three } \\
\text { modules: passenger, } \\
\text { safety and locomotion } \\
\text { (transport). }\end{array}$ & $\begin{array}{l}\text { tube system located largely } \\
\text { underground (pipe tunnels); } \\
\text { necessary infrastructure in } \\
\text { the form of stations, } \\
\text { airlocks, cross conveyors, } \\
\text { technical areas, emergency } \\
\text { chambers. }\end{array}$ \\
\hline
\end{tabular}

The concept of low pressure railway was developed within the framework of the implemented project. Its main assumption is its modularity. It is assumed that the vehicle is divided into the following modules: passenger/freight, safety and locomotion. The vehicle according to this concept would have one or both ends of the safety module opened, through which passenger or freight modules are inserted into its interior. This is shown in fig. 1.

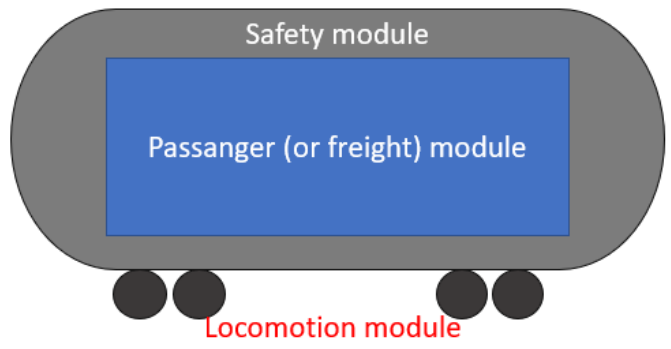

Fig. 1. Modular concept of a vehicle

The main author of the railroad concept, detailed technical solutions and aerodynamic analyses carried out [9] is professor Janusz Piechna. The main design and maintenance assumptions are as follows:

- pressure in the tunnel: $1000 \mathrm{~Pa}$, in the vehicle: atmospheric;

- maximum speed of the capsule: $720 \mathrm{~km} / \mathrm{h}$;

- maximum linear acceleration: $0.25 \mathrm{~g}\left(2.5 \mathrm{~m} / \mathrm{s}^{2}\right)$; 
- separation between vehicles: $24 \mathrm{~km}$ (2 min);

- wheel unit: standard wheel system with rolling bearings;

- maximum number of passengers in one vehicle: 30 or 56 .

The station concept assumes the separation of the following zones: safety control zone, platform hall, atmospheric pressure zone, low pressure zone. In addition, it is assumed to use special airlocks and cross conveyors to move the vehicle to the low pressure zone and then the appropriate tube (tunnel). During the rail ride, it was assumed that the acceleration and braking of the railroad will be carried out using linear motors and brakes. According to the developed concept, the vehicle will be accelerated to the maximum speed, then after the speed decreases to half of the maximum value, the vehicle will be accelerated using linear motors spaced every $300 \mathrm{~km}$. Moreover, emergency chambers will be used in the event of a system failure. In contrast to the other concepts considered [10], very high speeds (above $0.6 \mathrm{Ma}$ ) are not assumed. In such a case, it will be possible to use a traditional locomotion system and there will be no significant problems in ensuring the stability of the capsule movement. This will significantly reduce the construction complexity and cost of the project. A detailed description of the station concept and the technical infrastructure used can be found in [9].

\section{Hazard identification}

Hazard identification is the recognition of undesirable events that may occur at the workplace or while conducting a project, study, experiment, or using technical devices. Relevant here will be events that may occur during a railway ride and activities immediately before and after travel.

To initially identify hazards, undesirable events that may occur during the various stages of a low pressure railway vehicle ride were determined:

- Steps 1 and 11: Moving around the station;

- Step 2: Passing the security check;

- Steps 3 and 9: Entering/exiting the vehicle (passenger module) and taking up/leaving seats;

- Steps 4 and 8: Passenger module insertion/ejection from the safety capsule, crossing the airlock and low pressure zone;

- Steps 5 and 7: Accelerating or braking the vehicle;

- Step 6: Rail travel.

Steps (tasks) were divided into activities in order to be able to more precisely select undesirable events.

Possible undesirable events for each step and activity were identified in table 2. For each event the probable causes, effects, and suggested actions to eliminate or reduce the negative effects of the specified event were listed in table 3. 
Table 2

\section{Identification of undesirable events}

\begin{tabular}{|c|c|c|}
\hline Step / task & Activity / situation & Undesirable event (En) \\
\hline \multirow{6}{*}{$\begin{array}{l}\text { Steps } 1 \text { and } 11 \text { : Moving around } \\
\text { the station }\end{array}$} & Walking on the stairs & E1. Fall from stairs \\
\hline & \multirow{5}{*}{ Moving around the platform } & E2. Falling on a flat surface \\
\hline & & E3. Falling under a vehicle \\
\hline & & $\begin{array}{l}\text { E4. Contact with bacteria and } \\
\text { viruses }\end{array}$ \\
\hline & & $\begin{array}{l}\text { E5. Temperature too high, not } \\
\text { enough fresh air }\end{array}$ \\
\hline & & E6. Fire \\
\hline \multirow{2}{*}{$\begin{array}{l}\text { Step 2: Passing the security } \\
\text { check }\end{array}$} & \multirow{2}{*}{ Passing through the gate } & $\begin{array}{l}\text { E7. Contact with sharp edges } \\
\text { (suitcases, gates) }\end{array}$ \\
\hline & & E8. Impatience, weariness \\
\hline \multirow{7}{*}{$\begin{array}{l}\text { Steps } 3 \text { and 9: Entering/exiting } \\
\text { the vehicle (passenger module) } \\
\text { and taking up/leaving seats }\end{array}$} & \multirow{2}{*}{$\begin{array}{l}\text { Walking through the door } \\
\text { (cover) of passenger module to } \\
\text { take a seat }\end{array}$} & E9. Hitting \\
\hline & & E10. Contact with sharp edges \\
\hline & \multirow{2}{*}{$\begin{array}{l}\text { Closing / opening the door } \\
\text { (cover) of passenger module }\end{array}$} & $\begin{array}{l}\text { E11. Slamming the door (cover) on } \\
\text { hand }\end{array}$ \\
\hline & & E12. System failure \\
\hline & \multirow{2}{*}{ Loading luggage } & E13. Tipping over of a suitcase \\
\hline & & E14. Contact with sharp edges \\
\hline & Fastening /unfastening seat belts & $\begin{array}{l}\text { E15. Hooking the hand, cutting a } \\
\text { piece of skin with the seat belt } \\
\text { buckle }\end{array}$ \\
\hline \multirow{4}{*}{$\begin{array}{l}\text { Steps } 4 \text { and } 8 \text { : Passenger module } \\
\text { insertion/ejection from the safety } \\
\text { capsule, crossing the airlock and } \\
\text { low pressure zone }\end{array}$} & $\begin{array}{l}\text { Exit of the vehicle from the } \\
\text { tunnel }\end{array}$ & E16. Blocked entry to the station \\
\hline & \multirow{3}{*}{ Ride in the low pressure zone } & E17. Vehicle stopping \\
\hline & & $\begin{array}{l}\text { E18. Moving in the wrong } \\
\text { direction }\end{array}$ \\
\hline & & E19. Moving "against the flow" \\
\hline \multirow{2}{*}{\multicolumn{2}{|c|}{ Steps 5 and 7: Accelerating or braking the vehicle }} & E20. Falling out of the seat \\
\hline & & E21. Hitting \\
\hline \multirow{10}{*}{ Step 6: Rail travel } & \multirow{9}{*}{ Ride } & E22. Contact with sharp edges \\
\hline & & Z23. Fire \\
\hline & & $\begin{array}{l}\text { E24. Nausea, feeling of } \\
\text { claustrophobia during travel }\end{array}$ \\
\hline & & $\begin{array}{l}\text { E25. Feeling of boredom, } \\
\text { weariness, irritability }\end{array}$ \\
\hline & & $\begin{array}{l}\text { E26. Aggressive behavior / attack } \\
\text { of a other passenger, terrorist } \\
\text { attack }\end{array}$ \\
\hline & & $\begin{array}{l}\text { E27. Contact with bacteria and } \\
\text { viruses }\end{array}$ \\
\hline & & E28. Vehicle stopping \\
\hline & & $\begin{array}{l}\text { E29. Loss of safety capsule } \\
\text { containment }\end{array}$ \\
\hline & & E30. Tube damage \\
\hline & Emergency braking & E31. Hitting \\
\hline
\end{tabular}




\section{Analysis of causes and consequences of undesirable events}

\begin{tabular}{|c|c|c|c|}
\hline En & Causes & "Likely consequences & "Prevention / minimization activities \\
\hline E1 & $\begin{array}{l}\text { inattention, high stair } \\
\text { thresholds, slippery or wet } \\
\text { surfaces }\end{array}$ & $\begin{array}{l}\text { fractures, contusions, } \\
\text { cuts, sprains }\end{array}$ & $\begin{array}{l}\text { avoidance of high thresholds and stairs, } \\
\text { appropriate surface }\end{array}$ \\
\hline E2 & $\begin{array}{l}\text { passenger crowding, } \\
\text { inattention, slippery or } \\
\text { wet surfaces }\end{array}$ & $\begin{array}{l}\text { contusions, abrasions, } \\
\text { cuts, sprains }\end{array}$ & $\begin{array}{l}\text { appropriate surface, signage and marking of } \\
\text { station areas }\end{array}$ \\
\hline E3 & $\begin{array}{l}\text { inattention, lack of } \\
\text { protection }\end{array}$ & serious injuries & $\begin{array}{l}\text { safety measures to prevent falling under the } \\
\text { vehicle }\end{array}$ \\
\hline E4 & too many passengers & disease & $\begin{array}{l}\text { signage and marking of station areas, } \\
\text { ventilation, limiting the number of people, } \\
\text { measuring passenger temperature }\end{array}$ \\
\hline E5 & $\begin{array}{l}\text { too many passengers, } \\
\text { insufficient air } \\
\text { conditioning, long wait } \\
\text { for checking }\end{array}$ & $\begin{array}{l}\text { malaise, shortness of } \\
\text { breath, fainting }\end{array}$ & $\begin{array}{l}\text { appropriate ventilation and air-conditioning } \\
\text { system for platforms, short waiting time for } \\
\text { checking and travel }\end{array}$ \\
\hline E6 & fire started by a passenger & $\begin{array}{l}\text { smoke inhalation, } \\
\text { burns }\end{array}$ & $\begin{array}{l}\text { appropriate monitoring, smoke detectors, fire } \\
\text { protection }\end{array}$ \\
\hline E7 & $\begin{array}{l}\text { presence of sharp edges, } \\
\text { haste }\end{array}$ & cut (wound) & $\begin{array}{l}\text { avoiding sharp edges, developing a safe } \\
\text { security checking procedure }\end{array}$ \\
\hline E8 & $\begin{array}{l}\text { waiting too long for } \\
\text { checking }\end{array}$ & frustration & developing an efficient checking procedure \\
\hline E9 & $\begin{array}{l}\text { passenger crowding, } \\
\text { inattention }\end{array}$ & bruises, abrasions & supervising the entry of passengers \\
\hline E10 & $\begin{array}{l}\text { failure to protect sharp } \\
\text { edges, inattention }\end{array}$ & cuts, abrasions & avoiding sharp edges \\
\hline E11 & passenger inattention & hand injuries & $\begin{array}{l}\text { attention behavior, voice information about } \\
\text { door (cover) closing, sensors }\end{array}$ \\
\hline E12 & $\begin{array}{l}\text { faulty operation of the } \\
\text { door (cover) opening } \\
\text { system }\end{array}$ & frustration & $\begin{array}{l}\text { redundancy (emergency system) of door } \\
\text { (cover) opening }\end{array}$ \\
\hline E13 & $\begin{array}{l}\text { too much luggage, } \\
\text { uncomfortable place to } \\
\text { put luggage }\end{array}$ & abrasions & comfortable place to put luggage \\
\hline E14 & sharp edges & cut (wound) & avoiding sharp edges \\
\hline E15 & inattention & cut (wound) & safe belt system \\
\hline E16 & $\begin{array}{l}\text { failure of another vehicle, } \\
\text { conveyor failure of } \\
\text { another vehicle }\end{array}$ & $\begin{array}{l}\text { delays, need for } \\
\text { evacuation, need to } \\
\text { move the capsule }\end{array}$ & $\begin{array}{l}\text { use of the safety buffer concept, a procedure } \\
\text { in case of a conveyor failure in the low } \\
\text { pressure zone (e.g. use of the technical crane } \\
\text { to transfer the capsule) }\end{array}$ \\
\hline E17 & $\begin{array}{l}\text { cross conveyor failure, } \\
\text { vehicle failure }\end{array}$ & $\begin{array}{l}\text { delays, need for } \\
\text { evacuation, need to } \\
\text { move the capsule }\end{array}$ & $\begin{array}{l}\text { a procedure in case of a conveyor failure in } \\
\text { the low pressure zone (e.g. use of the } \\
\text { technical crane to transfer the capsule) }\end{array}$ \\
\hline E18 & system failure & $\begin{array}{l}\text { delays, travel to } \\
\text { another location }\end{array}$ & $\begin{array}{l}\text { developed traffic management and vehicle } \\
\text { tracking system }\end{array}$ \\
\hline E19 & system failure & $\begin{array}{l}\text { collision with another } \\
\text { vehicle, death }\end{array}$ & $\begin{array}{l}\text { developed traffic management and vehicle } \\
\text { tracking system }\end{array}$ \\
\hline E20 & $\begin{array}{l}\text { failure to wear seat belts, } \\
\text { excessive acceleration / } \\
\text { braking, linear motor / } \\
\text { brake failure }\end{array}$ & $\begin{array}{l}\text { contusions, injuries of } \\
\text { the head and whole } \\
\text { body }\end{array}$ & $\begin{array}{l}\text { voice messaging system for start/finish of } \\
\text { a ride and seatbelt buckle up, low } \\
\text { acceleration/ deceleration }\end{array}$ \\
\hline
\end{tabular}


tab. 3 cont

\begin{tabular}{|c|c|c|c|}
\hline E21 & $\begin{array}{l}\text { excessive } \\
\text { acceleration/braking, } \\
\text { linear motor/ brake failure }\end{array}$ & $\begin{array}{l}\text { contusions and head } \\
\text { injuries }\end{array}$ & $\begin{array}{l}\text { voice messaging system for start/finish of a } \\
\text { ride and seatbelt buckle up, low acceleration / } \\
\text { deceleration }\end{array}$ \\
\hline E22 & $\begin{array}{l}\text { lack of suitable cabin } \\
\text { interior finishing }\end{array}$ & cut (wound) & $\begin{array}{l}\text { avoidance/securing of sharp edges, interior } \\
\text { finishing with suitable fabrics / materials }\end{array}$ \\
\hline E23 & $\begin{array}{l}\text { prohibited activities - e.g. } \\
\text { smoking, use of lighters, } \\
\text { etc., short circuit of } \\
\text { electrical system }\end{array}$ & $\begin{array}{l}\text { burns, poisoning by } \\
\text { inhaled smoke, death }\end{array}$ & $\begin{array}{l}\text { video/thermovision monitoring, smoke } \\
\text { detectors, no lighters, smoking, etc., cabin } \\
\text { equipped with fire extinguisher, ability to } \\
\text { communicate with staff, avoid flammable } \\
\text { materials, develop evacuation procedures }\end{array}$ \\
\hline E24 & $\begin{array}{l}\text { insufficient ventilation / } \\
\text { air conditioning, } \\
\text { insufficient lighting, } \\
\text { inappropriate interior } \\
\text { design }\end{array}$ & $\begin{array}{l}\text { vomits, discomfort } \\
\text { during travel, } \\
\text { symptoms of motion } \\
\text { sickness }\end{array}$ & $\begin{array}{l}\text { providing efficient ventilation/air } \\
\text { conditioning system, choosing appropriate } \\
\text { lighting, installing video display system } \\
\text { during travel, arranging the interior in a way } \\
\text { that minimizes the feeling of claustrophobia }\end{array}$ \\
\hline E25 & $\begin{array}{l}\text { lack of appropriate } \\
\text { activities during travel }\end{array}$ & discomfort, frustration & $\begin{array}{l}\text { ensuring the possibility of using telephones } \\
\text { (wi-fi or mobile network availability), } \\
\text { installation of a system for displaying images } \\
\text { during travelling (monitors) }\end{array}$ \\
\hline E26 & $\begin{array}{l}\text { lack of appropriate } \\
\text { passenger checking }\end{array}$ & $\begin{array}{l}\text { cuts, injuries, } \\
\text { travel interruption, } \\
\text { evacuation, in case of } \\
\text { a terrorist attack: } \\
\text { serious injuries, death }\end{array}$ & $\begin{array}{l}\text { passenger checking for dangerous objects, } \\
\text { communication with staff, video monitoring } \\
\text { system, evacuation procedures }\end{array}$ \\
\hline E27 & $\begin{array}{l}\text { lack of appropriate } \\
\text { passenger checking, } \\
\text { lack of sufficient } \\
\text { ventilation, lack of } \\
\text { protective equipment, lack } \\
\text { of disinfection }\end{array}$ & disease & $\begin{array}{l}\text { checking of passenger's health condition } \\
\text { (temperature measurement), ensuring proper } \\
\text { ventilation/air-conditioning system, personal } \\
\text { protective equipment for passengers, } \\
\text { disinfecting the cabin after each ride }\end{array}$ \\
\hline E28 & $\begin{array}{l}\text { bearing failure, failure of } \\
\text { the low pressure } \\
\text { maintenance system }\end{array}$ & $\begin{array}{l}\text { delays, in extreme } \\
\text { cases derailment and } \\
\text { serious injury, need to } \\
\text { use emergency } \\
\text { vehicles and } \\
\text { evacuation }\end{array}$ & $\begin{array}{l}\text { use of double bearing or other technological } \\
\text { solution minimizing the risk of failure, } \\
\text { development of rescue and evacuation } \\
\text { procedures, high reliability of the low } \\
\text { pressure maintenance system }\end{array}$ \\
\hline E29 & design mistakes & $\begin{array}{l}\text { discomfort due to } \\
\text { pressure changes, } \\
\text { need to stop traveling } \\
\text { for repair and } \\
\text { evacuation } \\
\end{array}$ & $\begin{array}{l}\text { ensuring that the capsule is highly sealed, } \\
\text { equipping the vehicle with oxygen cylinders } \\
\text { and masks in case of loss of containment, } \\
\text { developing procedures for rescue and } \\
\text { evacuation }\end{array}$ \\
\hline E30 & $\begin{array}{l}\text { occurrence of } \\
\text { earthquakes, tectonic plate } \\
\text { movements, excavation } \\
\text { work at the location of a } \\
\text { tube system, large } \\
\text { temperature fluctuations, } \\
\text { terrorist attack }\end{array}$ & $\begin{array}{l}\text { vehicle stopping, need } \\
\text { to stop travelling and } \\
\text { evacuation, in extreme } \\
\text { cases damage to the } \\
\text { capsule and injury to } \\
\text { passengers }\end{array}$ & $\begin{array}{l}\text { avoidance of earthquake-prone areas, proper } \\
\text { protection of the site against unauthorized } \\
\text { work / terrorist attack, proper construction } \\
\text { (e.g., use of expansion joints), development } \\
\text { of rescue and evacuation procedures }\end{array}$ \\
\hline E31 & $\begin{array}{l}\text { failure of the vehicle in } \\
\text { front }\end{array}$ & $\begin{array}{l}\text { contusions and head } \\
\text { injuries, in extreme } \\
\text { cases damage to } \\
\text { vehicles and more } \\
\text { serious injuries }\end{array}$ & $\begin{array}{l}\text { integrated vehicle tracking system, } \\
\text { development of procedures for rescue and } \\
\text { evacuation }\end{array}$ \\
\hline
\end{tabular}


Attention should be paid to events related to failure of vehicles or conveyors - primarily events E16, E17, E28. In case of event E16: Blocked entry to the station, two scenarios can be distinguished:

a) failure of another vehicle while still in the tunnel - in this case, the conception of "safety buffer" is developed;

b) failure of another vehicle in the low pressure zone or its conveyor - in this case, a solution must be devised to allow emergency transfer of the capsule to another cross conveyor (perhaps using a technical crane).

In the case of event E17: Vehicle stopping while riding in the low pressure zone, a scenario can be distinguished that coincides with scenario b for event E16.

In case of event E28: Vehicle stopping during travel (e.g. bearings failure, failure of the low pressure maintenance system) the concept of using emergency stations, emergency vehicles and carrying out evacuation is provided.

Event E29: Loss of safety capsule containment forces the vehicle to be equipped with oxygen cylinders and masks and actions as in the previous event. However, it can be assumed that with high care in the design and construction of this capsule, the probability of this event occurrence is negligible.

Similarly, for event E30: Tube damage, procedures for conducting rescue and evacuation should be refined. Geodynamic monitoring of the earth should also be undertaken and the area should be secured against any unauthorized excavation works and the occurrence of a terrorist attack.

\section{Development of indicator method}

In this study, a proprietary indicator method is developed to assess the risk of low pressure railway transport. The defined risk indicator was based on the Risk Score method. Due to the fact that the analysis is conducted for one railway ride, the exposure factor was not considered (as opposed to the classical method). The risk score is as follows:

$$
R_{n}=P_{n} \cdot S_{n}
$$

where:

$n$ - undesirable event index (from 1 to 31 );

$R_{n}$ - risk score for the $\mathrm{n}^{\text {th }}$ undesirable event;

$P_{n}$ - probability of occurrence factor for the $\mathrm{n}^{\text {th }}$ undesirable event occurring during a single ride, taking values from 1 to 100 ;

$S_{n}$ - consequences (injuries severity) factor with values from 1 to 100 .

For all undesirable events the values of $P_{n}$ and $S_{n}$ were estimated by experts using the descriptive values provided in table 4 . The estimates were performed independently by the authors of the paper and are presented in table 5 . 
Table 4

Estimation of probability and consequences factors

\begin{tabular}{||c|l|c|c|c|c||}
\hline \multicolumn{2}{|c|}{ Probability factor $P_{n}$} & \multicolumn{3}{c||}{ Consequences factor $S_{n}$} \\
\hline$P_{n}$ & \multicolumn{1}{|c|}{ Descriptive } & Probability & $S_{n}$ & Loss & Descriptive \\
\hline 100 & Might well be expected & 0,5 & 100 & Catastrophe & many fatalities \\
\hline 60 & Quite possibly & 0,1 & 40 & Disaster & multiple fatalities \\
\hline 30 & Unusual, but possible & 0,01 & 15 & Very serious & a fatality \\
\hline 10 & Only remotely possible & 0,001 & 7 & Serious & serious injury \\
\hline 5 & Conceivable, but highly unlikely & 0,0001 & 3 & Important & disability \\
\hline 2 & Practically impossible & 0,00001 & \multirow{2}{*}{1} & Noticeable & $\begin{array}{c}\text { first aid may be } \\
\text { needed }\end{array}$ \\
\hline 1 & Virtually impossible & 0,000001 & & & \\
\hline
\end{tabular}

Table 5

\section{Expert estimations}

\begin{tabular}{|c|c|c|c|c|c|c|c|}
\hline \multirow{2}{*}{ Event $E n$} & \multicolumn{2}{|c|}{ Expert 1} & \multicolumn{2}{|c|}{ Expert 2} & \multicolumn{2}{|c|}{ "Mean value (MV) } & \multirow[b]{2}{*}{$R_{n}=P_{n \_M V} \cdot S_{n \_M V}$} \\
\hline & $P_{n}$ & $S_{n}$ & $P_{n}$ & $S_{n}$ & $P_{n \_M V}$ & $S_{n \_M V}$ & \\
\hline E1 & 2 & 3 & 8 & 3 & 5,0 & 3,0 & 15,0 \\
\hline E2 & 1 & 1 & 6 & 2 & 3,5 & 1,5 & 5,3 \\
\hline E3 & 1 & 3 & 3 & 10 & 2,0 & 6,5 & 13,0 \\
\hline E4 & 10 & 3 & 10 & 3 & 10,0 & 3,0 & 30,0 \\
\hline E5 & 5 & 1 & 10 & 1 & 7,5 & 1,0 & 7,5 \\
\hline E6 & 2 & 3 & 2 & 8 & 2,0 & 5,5 & 11,0 \\
\hline E7 & 5 & 1 & 10 & 1 & 7,5 & 1,0 & 7,5 \\
\hline E8 & 10 & 1 & 30 & 1 & 20,0 & 1,0 & 20,0 \\
\hline E9 & 2 & 1 & 10 & 1,5 & 6,0 & 1,3 & 7,5 \\
\hline E10 & 2 & 1 & 10 & 1 & 6,0 & 1,0 & 6,0 \\
\hline E11 & 2 & 3 & 4 & 2 & 3,0 & 2,5 & 7,5 \\
\hline E12 & 1 & 3 & 5 & 1 & 3,0 & 2,0 & 6,0 \\
\hline E13 & 2 & 1 & 25 & 1 & 13,5 & 1,0 & 13,5 \\
\hline E14 & 5 & 2 & 10 & 1 & 7,5 & 1,5 & 11,3 \\
\hline E15 & 2 & 1 & 10 & 1 & 6,0 & 1,0 & 6,0 \\
\hline E16 & 5 & 3 & 6 & 3 & 5,5 & 3,0 & 16,5 \\
\hline E17 & 2 & 15 & 3 & 15 & 2,5 & 15,0 & 37,5 \\
\hline E18 & 1 & 1 & 2 & 2 & 1,5 & 1,5 & 2,3 \\
\hline E19 & 0,1 & 100 & 0,2 & 40 & 0,2 & 70,0 & 10,5 \\
\hline E20 & 1 & 2 & 7 & 3 & 4,0 & 2,5 & 10,0 \\
\hline E21 & 2 & 1 & 10 & 2 & 6,0 & 1,5 & 9,0 \\
\hline E22 & 1 & 1 & 10 & 1 & 5,5 & 1,0 & 5,5 \\
\hline E23 & 1 & 15 & 4 & 10 & 2,5 & 12,5 & 31,3 \\
\hline E24 & 5 & 2 & 30 & 1,5 & 17,5 & 1,8 & 30,6 \\
\hline E25 & 10 & 1 & 35 & 1 & 22,5 & 1,0 & 22,5 \\
\hline E26 & 1 & 3 & 7 & 7 & 4,0 & 5,0 & 20,0 \\
\hline E27 & 30 & 3 & 15 & 3 & 22,5 & 3,0 & 67,5 \\
\hline E28 & 1 & 5 & 3 & 3 & 2,0 & 4,0 & 8,0 \\
\hline E29 & 1 & 40 & 1 & 25 & 1,0 & 32,5 & 32,5 \\
\hline E30 & 1 & 15 & 1 & 15 & 1,0 & 15,0 & 15,0 \\
\hline E31 & 2 & 3 & 3 & 3 & 2,5 & 3,0 & 7,5 \\
\hline
\end{tabular}

No risk score was obtained for any event to conclude that it is high (significant) and drastic preventive action is required. The events that need special attention in the final 
design of the railway transport system, the necessary infrastructure and their construction are the following:

- Contact with bacteria and viruses during rail travel;

- Vehicle stopping while riding in the low pressure zone ${ }^{1}$;

- Loss of safety capsule containment during rail travel;

- Fire during rail travel;

- Nausea, feeling of claustrophobia during rail travel;

- Contact with bacteria and viruses at the train station;

- Feeling of boredom, weariness, irritability during rail travel;

- Aggressive behavior / attack of a other passenger, terrorist attack;

- Impatience, weariness during the security check;

It can be noticed that the events with the highest risk score are usually associated with high potential consequences (loss of safety capsule containment, fire during travel, vehicle stopping while riding in the low pressure zone) or with high probability of occurrence (contact with viruses, fatigue, malaise). An exception is the event related to aggressive behavior of another passenger. In this case, the final score was evenly influenced by the probability and consequences factors. The experts showed a relatively high risk associated with the event involving contact with viruses and bacteria. This is mainly related to the epidemiological situation in Poland and in the world during the research work related to the Hyperloop project.

\section{Recommendations related to the development of the railway project}

Based on the conducted risk analysis, recommendations related to the development of the "Hyperloop" low pressure railway can be listed.

For the sake of ensuring an appropriate level of safety during the travel, it is necessary to provide appropriate systems and equipment components and take the following preventive measures:

- video/thermovision monitoring, use of appropriate smoke detectors and fire safety measures both at the station and in the vehicle;

- choosing appropriate materials for the seats (avoiding flammable materials);

- providing voice messages and an ability to communicate with staff;

- requiring staff and passengers to be equipped with personal protective equipment, installing hand disinfection dispensers at railway stations, frequent ventilation and disinfection of the station and vehicles;

\footnotetext{
${ }^{1}$ The high risk score for this event is due to the need to develop procedures in the event of a vehicle locomotion system or conveyor failure in the low pressure zone.
} 
- use of redundancy in the selection of mechanical systems, utmost care in the design of travel system and infrastructure;

- use of module tracking / traffic management system;

- equipping passenger modules with oxygen cylinders in case of loss of containment;

- developing procedures for conducting evacuation and rescue operations;

- developing a concept for transfer a vehicle in the event of a vehicle or conveyor failure in the low pressure zone;

- avoiding high steps and slippery surfaces in the station area, protecting against the possibility of falling under the vehicle;

- developing checking procedures.

In order to ensure an appropriate level of comfort during the use of the low pressure train in the context of minimizing the occurrence of fatigue, boredom, irritability or poor well-being, it is important to provide the following systems and equipment:

- ventilation and air conditioning system, ensuring fresh air supply and temperature comfort on the station and in the vehicle;

- selection of appropriate lighting inside the cabin;

- display system with monitors;

- mobile and/or Wi-Fi network ability;

- cabin interior layout to minimize the feeling of claustrophobia.

The above recommendations were developed primarily on the basis of the conducted detailed hazard identification. The conducted risk analysis showed the necessity to develop assumptions for proceeding in case of a failure of a vehicle locomotion system or a failure of a cross conveyor on which the vehicle is located in a low pressure zone.

\section{Summary and conclusions}

The analysis conducted was aimed at a preliminary risk assessment of the low pressure railway "Hyperloop", providing recommendations in the formation of the final design and construction of the railway system and the necessary infrastructure (stations, technical areas, tube system). The analysis to a significant extent was carried out in a classical way. It started with an analysis of the M-M-E system, identified undesirable events that could occur during moving around the station and during travel. Then, using a proprietary indicator method based on Risk Score, the potentially most dangerous events were selected. The events ranked with the highest risk score were: contact with viruses and bacteria during travel and at the station, loss of safety capsule containment, occurrence of fire, feeling of boredom, fatigue, irritability during the ride and security checks, aggressive behavior of another passenger, nausea, feeling of claustrophobia during the ride. It was also noticed that there is no concept of what to do in case of failure of the vehicle locomotion system or the conveyor on which the vehicle is located in the low pressure zone. Attention was drawn to the need for refinement of rescue and evacuation procedures in case of a failure during the ride. 
The safety analysis of the "Hyperloop" system should be extended after developing the detailed project of the railway system and the necessary infrastructure. This project should take considering the recommendations developed in this study.

\section{Acknowledgement}

This research was funded by The National Centre for Research and Development in Poland (Narodowe Centrum Badan i Rozwoju); project title: "Potential for the development and implementation of vacuum tube high-speed train technology in Poland in the social, technical, economic and legal context" ("Potencjat rozwoju i wdrażania w Polsce technologii kolei próżniowej w kontekście społecznym, technicznym, ekonomicznym i prawnym”); grant number: Gospostrateg/387144/27/NCBR/2019.

\section{References}

1. Almujibah H., Kaduk S. I., Preston J.: Hyperloop - prediction of social and physiological costs. Transportation Systems and Technology 2020. 6(3): 43-59, DOI: 10.17816/transsyst20206343-59.

2. DaTian Z., Wei X., Ali H., Han W.: Study on Model based Hazard Identification for the Hyperloop System. Proceedings of the International Seminar on Computation, Communication and Control 2015, DOI:10.2991/is3c-15.2015.6.

3. Fine W.: Mathematical Evaluations for Controlling Hazards. Journal of Safety Research 1971.

4. Gkoumas K., Christou M.: A triple-helix approach for the assessment of hyperloop potential in Europe. Sustainability 2020, DOI:10.3390/SU12197868.

5. Hansen I. A.: Hyperloop transport technology assessment and system analysis. Transportation Planning and Technology 2020,

DOI:10.1080/03081060.2020.1828935.

6. Jamroz K., Kadziński A., Chruzik K., et al.: Trans-Risk - An Integrated Method for Risk Management in Transport. Journal of Konbin 2010. 13(1): 209-220, DOI: 10.2478/v10040-008-0149-9.

7. Mateu J. M., Martínez Fernández P., Insa Franco R.: Setting safety foundations in the Hyperloop: A first approach to preliminary hazard analysis and safety assurance system. Safety Science 2021. 142: 105366, DOI: 10.1016/j.ssci.2021.105366.

8. Musk E.: Hyperloop Alpha. SpaceX/Tesla Motors 2013.

9. Piechna J.: Low Pressure Tube Transport - An Alternative to Ground Road Transport - Aerodynamic and Other Problems and Possible Solutions. Energies 2021. 14(13): 3766, DOI: 10.3390/en14133766.

10. Polak K.: Technologia Hyperloop i perspektywy jej zastosowania. Prace Instytutu Kolejnictwa 2017. 156: 28-32.

11. Sitarz M., Chruzik K., Wachnik R.: Aplication of RAMS and FMEA methods in safety management system of railway transport. Journal of Konbin 2012, DOI:10.2478/jok-2013-0061. 
12. Szopa T.: Niezawodność i bezpieczeństwo. Edition 2. Oficyna Wydawnicza PW, Warszawa 2016.

13. Szymajda M.: Koreański hyperloop rozpędził się do ponad $1000 \mathrm{~km} / \mathrm{h}$. Rynek Kolejowy 2020. https://www.rynek-kolejowy.pl/wiadomosci/koreanski-hyperlooprozpedzil-sie-do-ponad-1000-kmh-99557.html, access date: 01.09.2021.

14. Szymajda M.: Hyperloop Virgin po raz pierwszy pojechał z pasażerami. Rynek Kolejowy 2020. https://www.rynek-kolejowy.pl/wiadomosci/hyperloop-po-razpierwszy-pojechal-z-pasazerami-film-99456.html, access date: 25.09.2021.

15. Badania socjologiczne $\mathrm{w}$ symulatorze kolei próżniowej Hyperloop. https://www.biuletyn.pw.edu.pl/Wspolpraca-uczelni/Badania-socjologiczne-wsymulatorze-kolei-prozniowej-Hyperloop, access date: 01.09.2021.

16. PN-EN ISO 12100:2012. Bezpieczeństwo maszyn - Ogólne zasady projektowania Ocena ryzyka i zmniejszanie ryzyka.

17. Ustawa $\mathrm{z}$ dnia 28 marca 2003 r. o transporcie kolejowym (z późn. zm.), Dz.U.2020.1043 t.j.

18. Rozporządzenie Ministra Transportu i Gospodarki Morskiej z dnia 10 września 1998 r. w sprawie warunków technicznych, jakim powinny odpowiadać budowle kolejowe i ich usytuowanie (z późn. zm.), Dz.U.1998.151.987.

19. PN-EN 45545-2:2021-01. Kolejnictwo - Ochrona przeciwpożarowa w pojazdach szynowych - Część 2: Wymagania dla materiałów i elementów w zakresie właściwości ogniowych.

20. Ustawa z dnia 3 lipca 2002 r. Prawo lotnicze (z późn. zm.), Dz.U.2020.1970 t.j.

21. Rozporządzenie Parlamentu Europejskiego i Rady (WE) nr 300/2008 w zakresie specyfikacji dla krajowych programów kontroli jakości w dziedzinie ochrony lotnictwa cywilnego (z późn. zm.). 


\section{WSTĘPNA ANALIZA RYZYKA PODRÓŻY KOLEJĄ NISKOCIŚNIENIOWA}

\section{Wprowadzenie}

Działania na rzecz bezpieczeństwa dotyczą wielu aspektów życia człowieka i jego funkcjonowania w systemie człowiek - technika - otoczenie (C-T-O). Rozwój nauki o bezpieczeństwie związany jest $\mathrm{z}$ umiejętnością lepszej identyfikacji zagrożeń, uwzględnianiem zagadnień związanych $\mathrm{z}$ bezpieczeństwem na etapie projektowania urządzeń technicznych oraz postępem w zakresie przeciwdziałania zagrożeniom poprzez rozwijanie istniejących i proponowanie nowych metod analizy ryzyka i niezawodności [12]

Jednym z systemów, którego koncepcje są rozwijane na całym świecie, jest „Hyperloop”. Jest to sposób transportu, który można umieścić pomiędzy samolotem i pociągiem. Polega na przemieszczaniu się z bardzo dużą prędkością w specjalnie przygotowanej kapsule wewnątrz tunelu o obniżonym ciśnieniu [10]. Chociaż koncepcje przejazdu pojazdu wewnątrz rurociągu z obniżonym ciśnieniem były rozważane od lat, to za autora nazwy i założeń pojazdu „Hyperloop” uznaje się amerykańskiego przedsiębiorcę i multimiliardera Elona Muska. Zgodnie z jego ideą, pojazd ma być w porównaniu do innych środków transportu bezpieczniejszy, szybszy, tańszy, wygodniejszy, odporny na warunki atmosferyczne i trzęsienia ziemi, zrównoważony w kwestiach energetycznych oraz niekolizyjny [8]. Należy podkreślić, że w niektórych krajach - USA oraz Korei Południowej - prace są na tyle zaawansowane, że odbywają się już przejazdy testowe. W Korei przeprowadzono przejazdy testowe bez pasażerów z prędkościami ok. 700 oraz $1000 \mathrm{~km} / \mathrm{h}$ [13]. W USA odbył się przejazd z dwójką pasażerów na torze testowym o długości $500 \mathrm{~m} \mathrm{z}$ prędkością $160 \mathrm{~km} / \mathrm{h}$, bez pasażerów odbywała się seria przejazdów z prędkością ok. $400 \mathrm{~km} / \mathrm{h}$. Docelowo na dłuższym dystansie planowane jest przekroczenie prędkości $1000 \mathrm{~km} / \mathrm{h}$ [14]. W Polsce odbyły się badania w mechanicznym i wirtualnym symulatorze kolei [15]. Opis głównych założeń dotyczących funkcjonowania kolei niskociśnieniowej, której symulator zbudowano, można znaleźć w opracowaniu [9].

We wszystkich projektach dotyczących nowego sposobu przemieszczania się istotną rolę odgrywają analizy bezpieczeństwa. Z uwagi na brak odpowiednich norm i regulacji w tym zakresie, niezbędne jest odwoływanie się do uniwersalnych norm dotyczących bezpieczeństwa urządzeń technicznych [16], a także przepisów [17, 18] i norm (np. [19]) związanych z tradycyjną koleją. Pomocne mogą być również akty normatywne dotyczące zasad prowadzenia kontroli bezpieczeństwa w transporcie lotniczym [20, 21], ponadto należy rozważyć możliwość wykorzystania lekkich materiałów stosowanych w lotnictwie. 
Istotne mogą okazać się autorskie koncepcje i rozwiązania związane $\mathrm{z}$ analizą i zarządzaniem ryzykiem w transporcie $[6,11]$. Podejmowane są próby wypracowania odpowiednich rekomendacji związanych z technologią „Hyperloop” także w kontekście zarządzania systemem bezpieczeństwa na podstawie prowadzonych analiz ryzyka z wykorzystaniem: szczegółowego opisu i oceny poszczególnych własności, cech i segmentów omawianego systemu transportowego [5], map ryzyka i metody SWIFT (Structured What If Technique, Co-Jeżeli) [7], modelu zbliżonego do metody HAZOP (Hazard and Operability Study, analiza zagrożeń i zdolności operacyjnych) [2]. W prowadzonych badaniach można często znaleźć porównania i odwołania do istniejących systemów transportowych. Rozpatrywane są także kwestie związane z potencjałem w zakresie rozwoju technologicznego i komercjalizacji inwestycji [4] oraz akceptacją społeczną nowego środka transportu [1].

Przeprowadzona w pracy analiza ryzyka dotyczyć będzie aspektów związanych z bezpieczeństwem użytkowania oraz ergonomią systemu kolei niskociśnieniowej z wykorzystaniem jakościowej metody wskaźnikowej zbliżonej do Risk Score [3, 12]. Nie będą poddane analizie kwestie ekonomiczne czy społeczne związane $\mathrm{z}$ wdrażaniem systemu kolei niskociśnieniowej.

\section{Rozpoznanie systemu C-T-O}

Przed rozpoczęciem identyfikacji zagrożeń i poszukiwaniem możliwych do wystąpienia zdarzeń niepożądanych, istotne będzie określenie analizowanego systemu człowiek - technika - otoczenie (C-T-O). Identyfikacja poszczególnych członów systemu została przedstawiona w tab. 1 .

Tabela 1

\section{Identyfikacja systemu C-T-O}

\begin{tabular}{|c|c|c|}
\hline Człowiek & Technika & Otoczenie \\
\hline $\begin{array}{ll}\text { - } & \text { pasażerowie kolei } \\
\text { niskociśnieniowej } \\
\text { operatorzy - osoby } \\
\text { odpowiedzialne za } \\
\text { zarządzanie ruchem } \\
\text { kolei } \\
\text { - } \\
\text { obsługa (kolei, dworca) }\end{array}$ & $\begin{array}{l}\text { - kolej niskociśnieniowa } \\
\text { składająca się z trzech } \\
\text { modułów: } \\
\text { pasażerskiego, } \\
\text { bezpieczeństwa oraz } \\
\text { jezdnego }\end{array}$ & $\begin{array}{l}\text { - arteria rurowa znajdująca się } \\
\text { w dużej części pod ziemią } \\
\text { niezbędna infrastruktura } \\
\text { w postaci dworców, śluz, } \\
\text { przenośników poprzecznych, } \\
\text { obszarów technicznych, } \\
\text { komór ratunkowych }\end{array}$ \\
\hline
\end{tabular}

Koncepcja kolei niskociśnieniowej została opracowana w ramach realizowanego projektu. Głównym jej założeniem jest jej modułowość, zakłada się podział pojazdu na moduły: pasażerski/towarowy, bezpieczeństwa i jezdny. Pojazd według tej koncepcji miałby otwierany jeden lub dwa końce modułu bezpieczeństwa, przez które do jego wnętrza wsuwane są moduły pasażerskie lub moduły towarowe. Zaprezentowano to na rys. 1. 


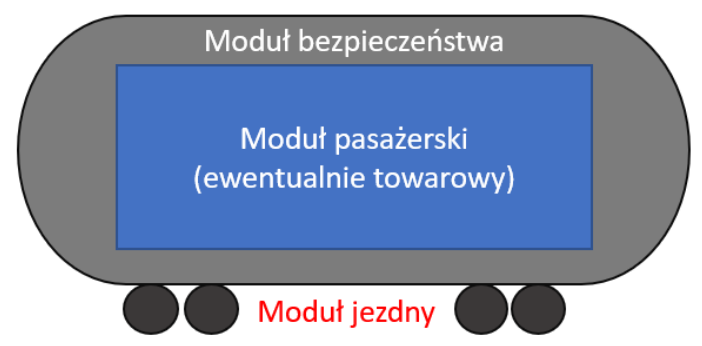

Rys. 1. Modułowa koncepcja pojazdu

Autorem koncepcji kolei, szczegółowych rozwiązań technicznych, a także przeprowadzonych analiz aerodynamicznych [9] jest profesor Janusz Piechna. Główne założenia konstrukcyjno-eksploatacyjne są następujące:

- ciśnienie w tunelu: $1000 \mathrm{~Pa}$, wewnątrz pojazdu: atmosferyczne,

- maksymalna prędkość kapsuły: $720 \mathrm{~km} / \mathrm{h}$,

- maksymalne przyspieszenia liniowe: $0,25 \mathrm{~g}\left(2,5 \mathrm{~m} / \mathrm{s}^{2}\right)$,

- separacja pomiędzy pojazdami: $24 \mathrm{~km}$ (2 min),

- moduł jezdny: standardowy układ kół z łożyskami tocznymi,

- maksymalna liczba pasażerów w jednej kapsule: 30 lub 56.

Koncepcja dworca (stacji pośredniej) zakłada wydzielenie następujących stref: strefa kontroli bezpieczeństwa, hala peronów, strefa ciśnienia atmosferycznego, strefa niskiego ciśnienia. Ponadto zakłada się wykorzystanie specjalnych śluz i przenośników poprzecznych, w celu przeniesienia pojazdu do strefy niskiego ciśnienia, a następnie odpowiedniej arterii rurowej. Podczas przejazdu kolei założono, że przyspieszenie oraz hamowanie kolei będzie odbywać się z wykorzystaniem liniowych silników i hamulców. Zgodnie z opracowaną koncepcją pojazd będzie rozpędzony do prędkości maksymalnej, następnie po spadku prędkości (do połowy wartości maksymalnej) nastąpi przyspieszenie pojazdu z wykorzystaniem siłowników liniowych rozmieszczonych co ok. $300 \mathrm{~km}$. Przewiduje się także odpowiednie rozmieszczenie komór ratunkowych na wypadek wystąpienia awarii systemu. W odróżnieniu od innych rozważanych koncepcji [10] nie zakłada się występowania bardzo wysokich prędkości (powyżej 0,6 Ma). W takim wypadku możliwe będzie zastosowanie tradycyjnego układu jezdnego oraz nie wystąpią znaczące problemy związane z zapewnieniem stabilności ruchu. Znacznie ograniczy to złożoność konstrukcji i koszty realizacji projektu. Szczegółowy opis koncepcji dworca oraz wykorzystywanej infrastruktury technicznej można znaleźć w [9].

\section{Identyfikacja zagrożeń}

Identyfikacja zagrożeń polega na określeniu zdarzeń niepożądanych, jakie mogą wystąpić na stanowisku pracy lub podczas prowadzenia projektu, badań, eksperymentu 
bądź użytkowania urządzenia. W tym przypadku istotne będą zdarzenia, które mogą zajść w trakcie przejazdu koleją oraz czynności bezpośrednio przed i po przejeździe.

W celu wstępnej identyfikacji zagrożeń określono zdarzenia niepożądane mogące wystąpić podczas poszczególnych etapów przejazdu pojazdem kolei niskociśnieniowej:

- etapy 1 i 11: Przemieszczenia się po dworcu,

- etap 2: Przejście kontroli bezpieczeństwa,

- etapy 3 i 9: Wchodzenie/wychodzenie z kabiny i zajmowanie/opuszczenie miejsc,

- etapy 4 i 8: Wsuwanie/wysuwanie się kabiny z kapsuły, przejazd przez śluzę i strefę niskiego ciśnienia,

- etapy 5 i 7: Rozpędzanie lub hamowanie pojazdu,

- $\quad$ etap 6: Przejazd koleją.

Etapy (zadania) podzielono na czynności, w celu możliwości bardziej precyzyjnego wytypowania zdarzeń niepożądanych.

W tab. 2 określono możliwe zdarzenia niepożądane dla poszczególnych etapów i czynności. W tab. 3 dla każdego zdarzenia wyszczególniono przypuszczalne przyczyny, skutki oraz sugestie działań mających na celu wyeliminowanie lub ograniczenie negatywnych skutków określonego zdarzenia.

\section{Tabela 2}

\section{Identyfikacja zdarzeń niepożądanych}

\begin{tabular}{|c|c|c|}
\hline Etap / zadanie & "Czynność / sytuacja & "Zdarzenia niepożądane (Zn) \\
\hline \multirow{6}{*}{$\begin{array}{l}\text { Etapy } 1 \text { i } 11 \text { : Przemieszczenie } \\
\text { się po dworcu }\end{array}$} & chodzenie po schodach & Z1. Upadek ze schodów \\
\hline & \multirow{5}{*}{$\begin{array}{l}\text { przemieszczanie się po } \\
\text { powierzchni peronu }\end{array}$} & Z2. Upadek na płaskiej powierzchni \\
\hline & & Z3. Wpadnięcie pod pojazd \\
\hline & & Z4. Kontakt $\mathrm{z}$ bakteriami i wirusami \\
\hline & & $\begin{array}{l}\text { Z5. Zbyt wysoka temperatura, mała } \\
\text { ilość świeżego powietrza }\end{array}$ \\
\hline & & Z6. Wystąpienie pożaru \\
\hline \multirow{2}{*}{$\begin{array}{l}\text { Etap 2: Przejście kontroli } \\
\text { bezpieczeństwa }\end{array}$} & \multirow{2}{*}{ przechodzenie przez bramkę } & $\begin{array}{l}\text { Z7. Kontakt z ostrymi krawędziami } \\
\text { (walizki, bramki) }\end{array}$ \\
\hline & & Z8. Zniecierpliwienie, znużenie \\
\hline \multirow{7}{*}{$\begin{array}{l}\text { Etapy } 3 \text { i 9: Wchodzenie/ } \\
\text { wychodzenie z kabiny } \\
\text { pasażerskiej } \\
\text { i zajmowanie/opuszczenie } \\
\text { miejsc }\end{array}$} & \multirow{2}{*}{$\begin{array}{l}\text { przechodzenie przez drzwi } \\
\text { (osłonę) kabiny w celu zajęcia } \\
\text { miejsca }\end{array}$} & Z9. Uderzenie się \\
\hline & & Z10. Kontakt z ostrymi krawędziami \\
\hline & \multirow{2}{*}{$\begin{array}{l}\text { zamykanie / otwieranie drzwi } \\
\text { (osłony) kabiny }\end{array}$} & Z11. Przytrzaśnięcie ręki \\
\hline & & Z12. Awaria systemu \\
\hline & \multirow{2}{*}{ wkładanie bagażu } & Z13. Przewrócenie się walizki \\
\hline & & Z14. Kontakt z ostrymi krawędziami \\
\hline & $\begin{array}{l}\text { zapinanie /odpinanie pasów } \\
\text { bezpieczeństwa }\end{array}$ & $\begin{array}{l}\text { Z15. Zahaczenie dłoni, przycięcie } \\
\text { fragmentu skóry klamrą pasów } \\
\text { bezpieczeństwa }\end{array}$ \\
\hline \multirow{4}{*}{$\begin{array}{l}\text { Etapy } 4 \text { i 8: } \\
\text { Wsuwanie/wysuwanie się } \\
\text { kabiny z kapsuły, przejazd } \\
\text { przez śluzę i strefę niskiego } \\
\text { ciśnienia }\end{array}$} & wyjazd z tunelu & $\begin{array}{l}\text { Z16. Zablokowanie możliwości } \\
\text { wjazdu na stację }\end{array}$ \\
\hline & \multirow{3}{*}{$\begin{array}{l}\text { przejazd w strefie niskiego } \\
\text { ciśnienia }\end{array}$} & Z17. Zatrzymanie się \\
\hline & & Z18. Pojechanie w złym kierunku \\
\hline & & Z19. Pojechanie pod prąd \\
\hline
\end{tabular}


cd. tab. 2

\begin{tabular}{|c|c|c|}
\hline \multirow{2}{*}{\multicolumn{2}{|c|}{ Etapy 5 i 7: Rozpędzanie lub hamowanie pojazdu }} & Z20. Wypadnięcie $\mathrm{z}$ fotela \\
\hline & & Z21. Uderzenie się \\
\hline \multirow{10}{*}{ Etap 6: Przejazd koleją } & \multirow{9}{*}{ przejazd } & Z22. Kontakt z ostrymi krawędziami \\
\hline & & Z23. Wystąpienie pożaru \\
\hline & & $\begin{array}{l}\text { Z24. Mdłości, uczucie klaustrofobii } \\
\text { podczas przejazdu }\end{array}$ \\
\hline & & $\begin{array}{l}\text { Z25. Poczucie nudy, znużenia, } \\
\text { rozdrażnienia }\end{array}$ \\
\hline & & $\begin{array}{l}\text { Z26. Agresywne zachowanie / atak } \\
\text { współuczestnika przejazdu, atak } \\
\text { terrorystyczny }\end{array}$ \\
\hline & & Z27. Kontakt $\mathrm{z}$ wirusami i bakteriami \\
\hline & & Z28. Zatrzymanie się pojazdu \\
\hline & & Z29. Rozszczelnienie kapsuły \\
\hline & & Z30. Uszkodzenie arterii rurowej \\
\hline & awaryjne hamowanie & Z31. Uderzenie się \\
\hline
\end{tabular}

Tabela 3

\section{Analiza przyczyn i skutków zdarzeń niepożądanych}

\begin{tabular}{|c|c|c|c|}
\hline Zn & Przyczyny & Prawdopodobne skutki & Działania zapobiegające / minimalizujące \\
\hline $\mathrm{Z1}$ & $\begin{array}{l}\text { nieuwaga, wysokie } \\
\text { progi, śliska lub mokra } \\
\text { powierzchnia }\end{array}$ & $\begin{array}{l}\text { złamania, stłuczenia, } \\
\text { skaleczenia, skręcenia }\end{array}$ & $\begin{array}{l}\text { unikanie wysokich progów i schodów, } \\
\text { odpowiednia nawierzchnia }\end{array}$ \\
\hline $\mathrm{Z} 2$ & $\begin{array}{l}\text { ścisk wśród pasażerów, } \\
\text { nieuwaga, śliska lub } \\
\text { mokra powierzchnia }\end{array}$ & $\begin{array}{l}\text { stłuczenia, otarcia, } \\
\text { skaleczenia, skręcenia }\end{array}$ & $\begin{array}{l}\text { odpowiednia nawierzchnia, odpowiednie } \\
\text { oznakowanie i oznaczenie stref dworca }\end{array}$ \\
\hline $\mathrm{Z3}$ & $\begin{array}{l}\text { nieuwaga, brak } \\
\text { zabezpieczeń }\end{array}$ & poważne obrażenia & $\begin{array}{l}\text { zabezpieczenia uniemożliwiające wpadnięcie } \\
\text { pod pojazd }\end{array}$ \\
\hline $\mathrm{Z4}$ & $\begin{array}{l}\text { zbyt duża liczba } \\
\text { pasażerów }\end{array}$ & choroba & $\begin{array}{l}\text { oznakowanie i oznaczenie stref dworca, } \\
\text { wietrzenie, ograniczanie liczby osób, pomiar } \\
\text { temperatury pasażerów }\end{array}$ \\
\hline $\mathrm{Z5}$ & $\begin{array}{l}\text { zbyt dużo pasażerów, } \\
\text { nieodpowiednia } \\
\text { klimatyzacja, długie } \\
\text { oczekiwanie na kontrolę }\end{array}$ & $\begin{array}{l}\text { złe samopoczucie, } \\
\text { duszności, omdlenia, } \\
\text { zasłabnięcia }\end{array}$ & $\begin{array}{l}\text { odpowiedni system wentylacji i klimatyzacji } \\
\text { peronów, niedługi czas oczekiwania na } \\
\text { kontrolę i przejazd }\end{array}$ \\
\hline Z6 & $\begin{array}{l}\text { wzniecenie ognia przez } \\
\text { pasażera }\end{array}$ & $\begin{array}{l}\text { wdychanie dymu, } \\
\text { poparzenia }\end{array}$ & $\begin{array}{l}\text { odpowiedni monitoring, czujniki dymu, } \\
\text { zabezpieczenia antypożarowe }\end{array}$ \\
\hline $\mathrm{Z7}$ & $\begin{array}{l}\text { występowanie ostrych } \\
\text { krawędzi, pośpiech }\end{array}$ & skaleczenie & $\begin{array}{l}\text { unikanie ostrych krawędzi, opracowanie } \\
\text { bezpiecznej procedury kontroli } \\
\text { bezpieczeństwa }\end{array}$ \\
\hline $\mathrm{Z} 8$. & $\begin{array}{l}\text { zbyt długie oczekiwanie } \\
\text { na kontrolę }\end{array}$ & frustracja & opracowanie sprawnej procedury kontroli \\
\hline Z9 & $\begin{array}{l}\text { ścisk wśród pasażerów, } \\
\text { nieuwaga }\end{array}$ & stłuczenia, otarcia & nadzór nad wchodzeniem pasażerów \\
\hline $\mathrm{Z} 10$ & $\begin{array}{l}\text { niezabezpieczenie } \\
\text { ostrych krawędzi, } \\
\text { nieuwaga }\end{array}$ & skaleczenia, otarcia & unikanie ostrych krawędzi \\
\hline $\mathrm{Z} 11$ & nieuwaga pasażera & urazy ręki & $\begin{array}{l}\text { zachowanie uwagi, informacja głosowa } \\
\text { o zamknięciu drzwi, czujnik }\end{array}$ \\
\hline $\mathrm{Z} 12$ & $\begin{array}{l}\text { nieodpowiednie } \\
\text { działanie systemu } \\
\text { otwierania drzwi }\end{array}$ & frustracja & $\begin{array}{l}\text { redundancja (system awaryjny) otwierania } \\
\text { drzwi }\end{array}$ \\
\hline
\end{tabular}


cd. tab. 3

\begin{tabular}{|c|c|c|c|}
\hline Z13 & $\begin{array}{l}\text { zbyt duży bagaż, } \\
\text { niewygodne miejsce do } \\
\text { wkładania bagażu }\end{array}$ & otarcia & wygodne miejsce do włożenia bagażu \\
\hline Z14 & ostre krawędzie & skaleczenia & unikanie ostrych krawędzi \\
\hline $\mathrm{Z15}$ & nieuwaga & skaleczenia & bezpieczny system pasów bezpieczeństwa \\
\hline Z16 & $\begin{array}{l}\text { awaria innego pojazdu, } \\
\text { awaria przenośnika } \\
\text { innego pojazdu }\end{array}$ & $\begin{array}{l}\text { opóźnienia, konieczność } \\
\text { ewakuacji, konieczność } \\
\text { przeniesienia kapsuły }\end{array}$ & $\begin{array}{l}\text { zastosowanie koncepcji bufora awaryjnego, } \\
\text { procedura na wypadek awarii przenośnika } \\
\text { w strefie niskiego ciśnienia (np. } \\
\text { wykorzystanie suwnicy do przeniesienia } \\
\text { kapsuły) }\end{array}$ \\
\hline Z17 & $\begin{array}{l}\text { awaria przenośnika } \\
\text { poprzecznego, awaria } \\
\text { pojazdu }\end{array}$ & $\begin{array}{l}\text { opóźnienia, konieczność } \\
\text { przeniesienia kapsuły, } \\
\text { konieczność ewakuacji }\end{array}$ & $\begin{array}{l}\text { procedura na wypadek awarii przenośnika } \\
\text { w strefie niskiego ciśnienia (np. } \\
\text { wykorzystanie suwnicy do przeniesienia } \\
\text { kapsuły) }\end{array}$ \\
\hline $\mathrm{Z} 18$ & awaria systemu & $\begin{array}{l}\text { opóźnienia, podróż } \\
\text { w inne miejsce }\end{array}$ & $\begin{array}{l}\text { opracowany system zarządzania ruchem } \\
\text { i śledzenia pojazdów }\end{array}$ \\
\hline Z19 & awaria systemu & $\begin{array}{l}\text { zderzenie } \mathrm{z} \text { innym } \\
\text { pojazdem, śmierć }\end{array}$ & $\begin{array}{l}\text { opracowany system zarządzania ruchem } \\
\text { i śledzenia pojazdów }\end{array}$ \\
\hline $\mathrm{Z} 20$ & $\begin{array}{l}\text { niezapięcie pasów, zbyt } \\
\text { gwałtowane } \\
\text { rozpędzanie/hamowanie, } \\
\text { awaria silnika } \\
\text { liniowego/hamulca }\end{array}$ & $\begin{array}{l}\text { stłuczenia i urazy głowy } \\
\text { oraz całego ciała }\end{array}$ & $\begin{array}{l}\text { system komunikatów głosowych informujący } \\
\text { o starcie/zakończeniu przejazdu i } \\
\text { konieczności zapięcia pasów, nieduże } \\
\text { przyspieszenie/ opóźnienie }\end{array}$ \\
\hline $\mathrm{Z} 21$ & $\begin{array}{l}\text { zbyt gwałtowane } \\
\text { rozpędzanie/hamowanie, } \\
\text { awaria silnika } \\
\text { liniowego/hamulca }\end{array}$ & stłuczenia i urazy głowy & $\begin{array}{l}\text { system komunikatów głosowych informujący } \\
\text { o starcie/zakończeniu przejazdu i } \\
\text { konieczności zapięcia pasów, nieduże } \\
\text { przyspieszenie/ opóźnienie }\end{array}$ \\
\hline $\mathrm{Z} 22$ & $\begin{array}{l}\text { brak odpowiedniego } \\
\text { wykończenia wnętrza } \\
\text { kabiny }\end{array}$ & skaleczenia & $\begin{array}{l}\text { unikanie/zabezpieczenie ostrych krawędzi, } \\
\text { wykończenie wnętrza odpowiednimi } \\
\text { tkaninami/materiałami }\end{array}$ \\
\hline $\mathrm{Z} 23$ & $\begin{array}{l}\text { czynności zakazane - } \\
\text { np. palenie papierosów, } \\
\text { używanie zapalniczek } \\
\text { itd., zwarcie instalacji } \\
\text { elektrycznej }\end{array}$ & $\begin{array}{l}\text { poparzenia, zatrucia } \\
\text { wdychanymi oparami, } \\
\text { śmierć }\end{array}$ & $\begin{array}{l}\text { monitoring wizyjny/termowizyjny, czujniki } \\
\text { dymu, zakaz używania zapalniczek, palenia } \\
\text { papierosów itd., wyposażenie kabiny w } \\
\text { gaśnicę, możliwość komunikowania się } \\
\text { z obsługą, unikanie materiałów } \\
\text { łatwopalnych, opracowanie procedur } \\
\text { ewakuacji }\end{array}$ \\
\hline $\mathrm{Z} 24$ & $\begin{array}{l}\text { brak odpowiedniej } \\
\text { wentylacji/klimatyzacji, } \\
\text { nieodpowiednie } \\
\text { oświetlenie, } \\
\text { nieodpowiednia } \\
\text { aranżacja wnętrza } \\
\end{array}$ & $\begin{array}{l}\text { wymioty, dyskomfort } \\
\text { podczas przejazdu, } \\
\text { objawy choroby } \\
\text { lokomocyjnej }\end{array}$ & $\begin{array}{l}\text { zapewnienie wydajnego systemu wentylacji/ } \\
\text { klimatyzacji, dobór odpowiedniego } \\
\text { oświetlenia, zamontowanie układu } \\
\text { wyświetlania obrazu podczas przejazdu, } \\
\text { zaaranżowanie wnętrza w sposób } \\
\text { minimalizujący uczucie klaustrofobii }\end{array}$ \\
\hline $\mathrm{Z} 25$ & $\begin{array}{l}\text { brak odpowiednich } \\
\text { zajęć podczas przejazdu }\end{array}$ & dyskomfort, frustracja & $\begin{array}{l}\text { zapewnienie możliwości korzystania } \\
\text { z telefonów (wi-fi lub dostępność sieci), } \\
\text { zamontowanie układu wyświetlania obrazu } \\
\text { podczas przejazdu (monitory) }\end{array}$ \\
\hline Z26 & $\begin{array}{l}\text { brak odpowiedniej } \\
\text { kontroli uczestników } \\
\text { przejazdu }\end{array}$ & $\begin{array}{l}\text { skaleczenia, urazy } \\
\text { przerwanie jazdy, } \\
\text { ewakuacja, w przypadku } \\
\text { ataku terrorystycznego: } \\
\text { poważne obrażenia, } \\
\text { śmierć }\end{array}$ & $\begin{array}{l}\text { kontrola pasażera pod kątem posiadania } \\
\text { niebezpiecznych przedmiotów, zapewnienie } \\
\text { możliwości komunikowania się z obsługą, } \\
\text { system monitoringu wizyjnego, opracowanie } \\
\text { procedur prowadzenia ewakuacji }\end{array}$ \\
\hline $\mathrm{Z} 27$ & $\begin{array}{l}\text { brak odpowiedniej } \\
\text { kontroli pasażerów, }\end{array}$ & choroba & $\begin{array}{l}\text { kontrola stanu zdrowia pasażera (pomiar } \\
\text { temperatury), zapewnienie odpowiedniego } \\
\text { systemu wentylacji /klimatyzacji, środki }\end{array}$ \\
\hline
\end{tabular}




\begin{tabular}{|c|c|c|c|}
\hline & $\begin{array}{l}\text { brak odpowiedniej } \\
\text { wentylacji, brak } \\
\text { środków ochrony, brak } \\
\text { dezynfekcji }\end{array}$ & & $\begin{array}{l}\text { ochrony osobistej dla pasażerów, } \\
\text { prowadzenie dezynfekcji kabiny po każdym } \\
\text { przejeździe }\end{array}$ \\
\hline $\mathrm{Z} 28$ & $\begin{array}{l}\text { zatarcie łożysk, awaria } \\
\text { systemu utrzymania } \\
\text { niskiego ciśnienia }\end{array}$ & $\begin{array}{l}\text { opóźnienia, w skrajnym } \\
\text { przypadku wykolejenie } \\
\text { i poważne obrażenia, } \\
\text { konieczność } \\
\text { wykorzystania } \\
\text { pojazdów ratunkowych } \\
\text { i ewakuacja }\end{array}$ & $\begin{array}{l}\text { zastosowanie podwójnego łożyskowania lub } \\
\text { innego rozwiązania technologicznego } \\
\text { minimalizującego ryzyko zatarcia, } \\
\text { opracowanie procedur prowadzenia akcji } \\
\text { ratunkowej i ewakuacji, wysoka } \\
\text { niezawodność systemu utrzymania niskiego } \\
\text { ciśnienia }\end{array}$ \\
\hline Z29 & błędy projektowe & $\begin{array}{l}\text { dolegliwości związane } \\
\text { ze zmianą ciśnienia, } \\
\text { konieczność przerwania } \\
\text { jazdy w celu naprawy } \\
\text { i ewakuacja }\end{array}$ & $\begin{array}{l}\text { zapewnienie wysokiej szczelności kapsuły, } \\
\text { wyposażenie pojazdu w butle z tlenem } \\
\text { i maseczki na wypadek rozszczelnienia, } \\
\text { opracowanie procedur prowadzenia akcji } \\
\text { ratunkowej i ewakuacji }\end{array}$ \\
\hline $\mathrm{Z} 30$ & $\begin{array}{l}\text { wystąpienie trzęsienia } \\
\text { ziemi, ruchów płyt } \\
\text { tektonicznych, } \\
\text { prowadzenie prac } \\
\text { wydobywczych } \\
\text { w miejscu znajdowania } \\
\text { się arterii rurowej, duże } \\
\text { wahania temperatury, } \\
\text { atak terrorystyczny }\end{array}$ & $\begin{array}{l}\text { zatrzymanie się pojazdu, } \\
\text { konieczność przerwania } \\
\text { jazdy i ewakuacji, } \\
\text { w skrajnym przypadku } \\
\text { uszkodzenia kapsuły } \\
\text { i obrażenia pasażerów }\end{array}$ & $\begin{array}{l}\text { unikanie terenów zagrożonych trzęsieniami } \\
\text { ziemi, odpowiednie zabezpieczenie terenu } \\
\text { przed wykonywaniem niedozwolonych robót } \\
\text { / atakami terrorystycznymi, odpowiednia } \\
\text { konstrukcja (np. zastosowanie szczelin } \\
\text { dylatacyjnych), opracowanie procedur akcji } \\
\text { ratunkowej i prowadzenia ewakuacji }\end{array}$ \\
\hline $\mathrm{Z} 31$ & $\begin{array}{l}\text { awaria pojazdu } \\
\text { znajdującego się z } \\
\text { przodu }\end{array}$ & $\begin{array}{l}\text { stłuczenia i urazy } \\
\text { głowy, w skrajnym } \\
\text { wypadku uszkodzenie } \\
\text { pojazdów } \\
\text { i poważniejsze } \\
\text { obrażenia }\end{array}$ & $\begin{array}{l}\text { zintegrowany system śledzenia } \\
\text { przemieszczania się pojazdów, opracowanie } \\
\text { procedur prowadzenia akcji ratunkowej } \\
\text { i ewakuacji }\end{array}$ \\
\hline
\end{tabular}

Należy zwrócić uwagę na zdarzenia związane z awarią pojazdów lub przenośników przede wszystkim zdarzenia Z16, Z17, Z28. W przypadku zdarzenia Z16: Zablokowanie możliwości wjazdu na stację można wyróżnić dwa scenariusze:

a) awaria innego pojazdu jeszcze w tunelu - w tym wypadku opracowana jest koncepcja tzw. bufora awaryjnego;

b) awaria innego pojazdu znajdującego się w strefie niskiego ciśnienia lub jego przenośnika - w tym wypadku należy opracować rozwiązanie umożliwiające awaryjne przeniesienie kapsuły na inny przenośnik poprzeczny (być może z wykorzystaniem suwnicy technicznej).

W przypadku zdarzenia Z17: Zatrzymanie się podczas przejazdu $w$ strefie niskiego cieśnienia można wyróżnić scenariusz zbieżny ze scenariuszem b dotyczącym zdarzenia Z16.

W przypadku zdarzenia Z28: Zatrzymanie się podczas przejazdu (np. zatarcie łożysk, awaria systemu utrzymania niskiego ciśnienia) przewidziana jest koncepcja wykorzystania stacji awaryjnych, pojazdów ratunkowych oraz przeprowadzenia ewakuacji.

Zdarzenie Z29: Rozszczelnienie kapsuly wymusza wyposażenie pojazdu w butle z tlenem i maski oraz czynności takie jak w przypadku poprzedniego zdarzenia. Jednak 
można założyć, że przy zachowaniu wysokiej staranności przy projekcie i wykonaniu takiej kapsuły, prawdopodobieństwo wystąpienia takiego zdarzenia jest znikome.

Podobnie dla zdarzenia Z30: Uszkodzenie arterii rurowej należy dopracować procedury prowadzenia akcji ratunkowej i ewakuacji. Należy także podjąć działania monitoringu geodynamicznego ziemi oraz zabezpieczyć teren przed prowadzeniem ewentualnych niedozwolonych robót i wystąpieniem ataku terrorystycznego.

\section{Opracowanie metody wskaźnikowej}

W niniejszej pracy opracowano autorską metodę wskaźnikową do oceny ryzyka przejazdu koleją. Zdefiniowany wskaźnik ryzyka wzorowano na metodzie Risk Score. Z uwagi na fakt, że analiza dotyczy jednego przejazdu koleją, nie uwzględniono wskaźnika związanego z ekspozycją (w odróżnieniu od klasycznego podejścia). Wskaźnik ryzyka jest więc następujący:

$$
R_{n}=P_{n} \cdot S_{n}
$$

gdzie:

$n$ - indeks zdarzenia niepożądanego (od 1 do 31),

$R_{n}$ - wskaźnik ryzyka dla $n$-tego zdarzenia niepożądanego,

$P_{n}$ - wskaźnik prawdopodobieństwa wystąpienia $n$-tego zdarzenia niepożądanego podczas jednego przejazdu przyjmujący wartości od 1 do 100 ,

$S_{n}$ - wskaźnik ciężkości skutków przyjmujący wartości od 1 do 100.

Wartości wskaźników $P_{n}$ oraz $S_{n}$ zostały oszacowane dla zdarzeń niepożądanych przez ekspertów z wykorzystaniem wartości opisowych zamieszczonych w tab. 4. Oszacowania dokonali niezależnie autorzy pracy, przedstawia je tab. 5 .

Tabela 4

\section{Szacowanie wskaźników prawdopodobieństwa i skutków}

\begin{tabular}{||c|l|c|c|c|c||}
\hline \multicolumn{3}{|c|}{ Wskaźnik prawdopodobieństwa $P_{n}$} & \multicolumn{3}{c||}{ Wskaźnik skutków $S_{n}$} \\
\hline$P_{n}$ & \multicolumn{1}{|c|}{ Opis } & Prawdop. & $S_{n}$ & Strata & Opis \\
\hline 100 & bardzo prawdopodobne & 0,5 & 100 & poważna katastrofa & wiele ofiar śmiertelnych \\
\hline 60 & całkiem możliwe & 0,1 & 40 & katastrofa & kilka ofiar śmiertelnych \\
\hline 30 & mało prawdop., ale możliwe & 0,01 & 15 & bardzo duża & ofiara śmiertelna \\
\hline 10 & tylko sporadycznie możliwe & 0,001 & 7 & duża & ciężkie uszkodz. ciała \\
\hline 5 & możliwe do pomyślenia & 0,0001 & 3 & średnia & zwolnienie lekarskie \\
\hline 2 & praktycznie niemożliwe & 0,00001 & \multirow{2}{*}{1} & mała & $\begin{array}{c}\text { opatrzenie } \\
\text { poszkodowanego }\end{array}$ \\
\hline 1 & tylko teoretycznie możliwe & 0,000001 & & &
\end{tabular}


Tabela 5

Szacowania eksperckie

\begin{tabular}{|c|c|c|c|c|c|c|c|}
\hline \multirow{2}{*}{$\begin{array}{c}\text { Zdarzenie } \\
Z n\end{array}$} & \multicolumn{2}{|c|}{ Ekspert 1} & \multicolumn{2}{|c|}{ Ekspert 2} & \multicolumn{2}{|c|}{ Średnia } & \multirow[b]{2}{*}{$R_{n}=P_{n_{-} \dot{s} r} \cdot S_{n_{-} s r}$} \\
\hline & $P_{n}$ & $S_{n}$ & $P_{n}$ & $S_{n}$ & $P_{n \dot{s} r}$ & $S_{n \dot{s} r}$ & \\
\hline $\mathrm{Z1}$ & 2 & 3 & 8 & 3 & 5,0 & 3,0 & 15,0 \\
\hline $\mathrm{Z2}$ & 1 & 1 & 6 & 2 & 3,5 & 1,5 & 5,3 \\
\hline $\mathrm{Z3}$ & 1 & 3 & 3 & 10 & 2,0 & 6,5 & 13,0 \\
\hline $\mathrm{Z4}$ & 10 & 3 & 10 & 3 & 10,0 & 3,0 & 30,0 \\
\hline $\mathrm{Z5}$ & 5 & 1 & 10 & 1 & 7,5 & 1,0 & 7,5 \\
\hline Z6 & 2 & 3 & 2 & 8 & 2,0 & 5,5 & 11,0 \\
\hline $\mathrm{Z7}$ & 5 & 1 & 10 & 1 & 7,5 & 1,0 & 7,5 \\
\hline $\mathrm{Z8}$ & 10 & 1 & 30 & 1 & 20,0 & 1,0 & 20,0 \\
\hline Z9 & 2 & 1 & 10 & 1,5 & 6,0 & 1,3 & 7,5 \\
\hline $\mathrm{Z10}$ & 2 & 1 & 10 & 1 & 6,0 & 1,0 & 6,0 \\
\hline Z11 & 2 & 3 & 4 & 2 & 3,0 & 2,5 & 7,5 \\
\hline $\mathrm{Z12}$ & 1 & 3 & 5 & 1 & 3,0 & 2,0 & 6,0 \\
\hline Z13 & 2 & 1 & 25 & 1 & 13,5 & 1,0 & 13,5 \\
\hline Z14 & 5 & 2 & 10 & 1 & 7,5 & 1,5 & 11,3 \\
\hline Z15 & 2 & 1 & 10 & 1 & 6,0 & 1,0 & 6,0 \\
\hline Z16 & 5 & 3 & 6 & 3 & 5,5 & 3,0 & 16,5 \\
\hline Z17 & 2 & 15 & 3 & 15 & 2,5 & 15,0 & 37,5 \\
\hline Z18 & 1 & 1 & 2 & 2 & 1,5 & 1,5 & 2,3 \\
\hline Z19 & 0,1 & 100 & 0,2 & 40 & 0,2 & 70,0 & 10,5 \\
\hline $\mathrm{Z} 20$ & 1 & 2 & 7 & 3 & 4,0 & 2,5 & 10,0 \\
\hline Z21 & 2 & 1 & 10 & 2 & 6,0 & 1,5 & 9,0 \\
\hline $\mathrm{Z} 22$ & 1 & 1 & 10 & 1 & 5,5 & 1,0 & 5,5 \\
\hline $\mathrm{Z} 23$ & 1 & 15 & 4 & 10 & 2,5 & 12,5 & 31,3 \\
\hline Z24 & 5 & 2 & 30 & 1,5 & 17,5 & 1,8 & 30,6 \\
\hline $\mathrm{Z} 25$ & 10 & 1 & 35 & 1 & 22,5 & 1,0 & 22,5 \\
\hline Z26 & 1 & 3 & 7 & 7 & 4,0 & 5,0 & 20,0 \\
\hline $\mathrm{Z} 27$ & 30 & 3 & 15 & 3 & 22,5 & 3,0 & 67,5 \\
\hline Z28 & 1 & 5 & 3 & 3 & 2,0 & 4,0 & 8,0 \\
\hline Z29 & 1 & 40 & 1 & 25 & 1,0 & 32,5 & 32,5 \\
\hline $\mathrm{Z} 30$ & 1 & 15 & 1 & 15 & 1,0 & 15,0 & 15,0 \\
\hline Z31 & 2 & 3 & 3 & 3 & 2,5 & 3,0 & 7,5 \\
\hline
\end{tabular}

Dla żadnego zdarzenia nie otrzymano wskaźnika ryzyka pozwalającego stwierdzić, że jest ono wysokie (istotne) i wymagane jest podjęcie drastycznych działań zapobiegawczych. Zdarzenia, na które należy zwrócić szczególną uwagę przy ostatecznym projekcie kolei, niezbędnej infrastruktury $\mathrm{i}$ ich budowie są następujące:

- kontakt z wirusami i bakteriami podczas przejazdu,

- zatrzymanie się podczas przejazdu przez strefę niskiego ciśnienia ${ }^{1}$,

- rozszczelnienie kapsuły podczas przejazdu,

- wystąpienie pożaru podczas przejazdu,

- mdłości, uczucie klaustrofobii podczas przejazdu,

1 Wysoki wskaźnik ryzyka dla tego zdarzenia wynika z konieczności opracowania procedur na wypadek awarii układu kołowego pojazdu lub przenośnika w strefie niskiego ciśnienia 
- kontakt z bakteriami i wirusami na dworcu,

- poczucie nudy, znużenia, rozdrażnienia podczas przejazdu,

- agresywne zachowanie / atak współuczestnika przejazdu, atak terrorystyczny,

- zniecierpliwienie, znużenie podczas kontroli bezpieczeństwa.

Można zauważyć, że zdarzenia o najwyższym wskaźniku ryzyka wiążą się zazwyczaj z wysokimi potencjalnymi skutkami (rozszczelnienie kapsuły, wystąpienie pożaru podczas przejazdu, zatrzymanie się podczas przejazdu przez strefę niskiego ciśnienia) lub z wysokim prawdopodobieństwem ich wystąpienia (kontakt z wirusami, znużenie, złe samopoczucie). Wyjątkiem jest zdarzenie związane $\mathrm{z}$ agresywnym zachowaniem współuczestnika podróży. W tym przypadku na ostateczny wynik równomierny wpływ miały wskaźniki prawdopodobieństwa i skutków. Eksperci wykazali stosunkowe duże niebezpieczeństwo związane ze zdarzeniem polegającym na kontakcie $\mathrm{z}$ wirusami i bakteriami. Jest to związane głównie z sytuacją epidemiologiczną w Polsce i na świecie podczas prowadzenia prac badawczych związanych z projektem „Hyperloop”.

\section{Rekomendacje związane $z$ opracowaniem projektu kolei}

$\mathrm{Na}$ podstawie przeprowadzonej analizy ryzyka można wymienić rekomendacje i zalecenia związane z budową kolei niskociśnieniowej „Hyperloop”.

Ze względu na zapewnienie odpowiedniego poziomu bezpieczeństwa podczas przejazdu jest niezbędne zapewnienie odpowiednich systemów oraz elementów wyposażenia oraz podjęcie następujących działań zapobiegawczych:

- kamery wizyjne/termowizyjne, zastosowanie odpowiednich czujników dymu i środków ochrony przeciwpożarowych zarówno na dworcu jak i w pojeździe;

- dobór odpowiedniego materiału do foteli (unikanie materiałów łatwopalnych);

- zapewnienie komunikacji głosowej i możliwość komunikowania się z obsługą;

- wymaganie od personelu i pasażerów zaopatrzenia w środki ochrony osobistej, zamontowanie na dworcach dozowników do dezynfekcji dłoni, częste wietrzenie i dezynfekowanie dworca oraz pojazdów;

- zastosowanie redundancji w zakresie doboru systemów mechanicznych, najwyższa staranność podczas projektowania konstrukcji i infrastruktury;

- zastosowanie systemu śledzenia / zarządzania ruchem modułów;

- wyposażenie modułów pasażerskich w butle z tlenem na wypadek rozszczelnienia;

- opracowanie procedur przeprowadzenia ewakuacji i akcji ratunkowej;

- opracowanie koncepcji przeniesienia modułu na wypadek awarii pojazdu lub przenośnika w strefie niskiego ciśnienia;

- unikanie wysokich stopni oraz śliskich powierzchni na terenie dworca, zabezpieczenie przed możliwością wpadnięcia pod pojazd;

- opracowanie procedur kontroli bezpieczeństwa.

Ze względu na zapewnienie odpowiedniego poziomu komfortu podczas użytkowania koeli niskociśnieniowej w kontekście minimalizacji wystąpienia znużenia, poczucia nudy, 
rozdrażnienia czy złego samopoczucie jest istotne zapewnienie następujących systemów oraz elementów wyposażenia:

- układ wentylacji i klimatyzacji, zapewniający dopływ świeżego powietrza oraz komfort temperaturowy na dworcu i w pojeździe;

- dobór odpowiedniego oświetlenia wewnątrz kabiny;

- układ wyświetlania obrazów za pomocą monitorów;

- zapewnienie zasięgu sieci komórkowej i/lub sieci wifi;

- zaaranżowanie wnętrza kabiny w sposób minimalizujący uczucie klaustrofobii.

Powyższe rekomendacje zostały opracowane przede wszystkim na podstawie przeprowadzonej szczegółowej identyfikacji zagrożeń. Przeprowadzona analiza ryzyka wykazała konieczność opracowania założeń w zakresie postępowania w przypadku awarii zestawu kołowego pojazdu lub awarii przenośnika poprzecznego na którym znajduje się pojazd w strefie niskiego ciśnienia.

\section{Podsumowanie i wnioski}

Przeprowadzona analiza miała na celu wstępną ocenę ryzyka kolei niskociśnieniowej „Hyperloop”, dostarczając rekomendacji przy powstaniu ostatecznego projektu i budowie kolei oraz niezbędnej infrastruktury (dworce, obszary techniczne, arteria rurowa). Analiza w znaczącym zakresie została przeprowadzona w sposób klasyczny. Rozpoczęto od analizy systemu C-T-O, określono zdarzenia niepożądane mogące wystąpić podczas pobytu na dworcu oraz w trakcie przejazdu. Następnie, wykorzystując autorską metodę wskaźnikową wzorowaną na Risk Score, wytypowano potencjalnie najbardziej niebezpieczne zdarzenia. Jako zdarzenia klasyfikujące się największym wskaźnikiem ryzyka uznano: kontakt z wirusami i bakteriami podczas przejazdu i na dworcu, rozszczelnienie kapsuły podczas przejazdu, wystąpienie pożaru, poczucie nudy, znużenia, rozdrażnienia podczas przejazdu i kontroli bezpieczeństwa, agresywne zachowanie współuczestnika przejazdu, mdłości, uczucie klaustrofobii podczas przejazdu. Dostrzeżono także brak koncepcji postępowania w przypadku wystąpienia awarii układu kołowego pojazdu lub przenośnika na którym znajduje się pojazd w strefie niskiego ciśnienia. Zwrócono uwagę na potrzebę dopracowania procedur akcji ratunkowej i ewakuacji w przypadku wystąpienia awarii podczas przejazdu.

Analiza bezpieczeństwa systemu „Hyperloop” powinna być rozszerzona po opracowaniu szczegółowego projektu kolei i niezbędnej infrastruktury, który powinien uwzględniać zalecenia opracowane w niniejszej pracy.

\section{Podziękowanie}

Badania byly finansowane przez Narodowe Centrum Badan i Rozwoju; tytut projektu: „Potencjat rozwoju $i$ wdrażania $w$ Polsce technologii kolei próżniowej $w$ kontekście społecznym, technicznym, ekonomicznym i prawnym”; numer umowy: Gospostrateg/ 387144/27/NCBR/2019. 


\section{Literatura}

1. Almujibah H., Kaduk S. I., Preston J.: Hyperloop - prediction of social and physiological costs. Transportation Systems and Technology 2020. 6(3): 43-59, DOI: 10.17816/transsyst20206343-59.

2. DaTian Z., Wei X., Ali H., Han W.: Study on Model based Hazard Identification for the Hyperloop System. Proceedings of the International Seminar on Computation, Communication and Control 2015, DOI:10.2991/is3c-15.2015.6.

3. Fine W.: Mathematical Evaluations for Controlling Hazards. Journal of Safety Research 1971.

4. Gkoumas K., Christou M.: A triple-helix approach for the assessment of hyperloop potential in Europe. Sustainability 2020, DOI:10.3390/SU12197868.

5. Hansen I. A.: Hyperloop transport technology assessment and system analysis. Transportation Planning and Technology 2020, DOI:10.1080/03081060.2020.1828935.

6. Jamroz K., Kadziński A., Chruzik K., et al.: Trans-Risk - An Integrated Method for Risk Management in Transport. Journal of Konbin 2010. 13(1): 209-220, DOI: 10.2478/v10040-008-0149-9.

7. Mateu J. M., Martínez Fernández P., Insa Franco R.: Setting safety foundations in the Hyperloop: A first approach to preliminary hazard analysis and safety assurance system. Safety Science 2021. 142: 105366, DOI: 10.1016/j.ssci.2021.105366.

8. Musk E.: Hyperloop Alpha. SpaceX/Tesla Motors 2013.

9. Piechna J.: Low Pressure Tube Transport - An Alternative to Ground Road Transport - Aerodynamic and Other Problems and Possible Solutions. Energies 2021. 14(13): 3766, DOI: 10.3390/en14133766.

10. Polak K.: Technologia Hyperloop i perspektywy jej zastosowania. Prace Instytutu Kolejnictwa 2017. Zeszyt 156: 28-32.

11. Sitarz M, Chruzik K, Wachnik R.: Aplication of RAMS and FMEA methods in safety management system of railway transport. Journal of Konbin 2012, DOI:10.2478/jok2013-0061.

12. Szopa T.: Niezawodność i bezpieczeństwo. Edycja 2. Oficyna Wydawnicza PW, Warszawa 2016.

13. Szymajda M.: Koreański hyperloop rozpędził się do ponad $1000 \mathrm{~km} / \mathrm{h}$. Rynek Kolejowy 2020. https://www.rynek-kolejowy.pl/wiadomosci/koreanski-hyperlooprozpedzil-sie-do-ponad-1000-kmh-99557.html, data dostępu: 01.09.2021

14. Szymajda M.: Hyperloop Virgin po raz pierwszy pojechał z pasażerami. Rynek Kolejowy 2020. https://www.rynek-kolejowy.pl/wiadomosci/hyperloop-po-razpierwszy-pojechal-z-pasazerami-film-99456.html, data dostępu: 25.09.2021.

15. Badania socjologiczne w symulatorze kolei próżniowej Hyperloop. https://www.biuletyn.pw.edu.pl/Wspolpraca-uczelni/Badania-socjologiczne-wsymulatorze-kolei-prozniowej-Hyperloop, data dostępu: 01.09.2021.

16. PN-EN ISO 12100:2012. Bezpieczeństwo maszyn - Ogólne zasady projektowania - 
Ocena ryzyka i zmniejszanie ryzyka.

17. Ustawa z dnia 28 marca 2003 r. o transporcie kolejowym (z późn. zm.), Dz.U.2020.1043 t.j.

18. Rozporządzenie Ministra Transportu i Gospodarki Morskiej z dnia 10 września 1998 r. w sprawie warunków technicznych, jakim powinny odpowiadać budowle kolejowe i ich usytuowanie (z późn. zm.), Dz.U.1998.151.987.

19. PN-EN 45545-2:2021-01. Kolejnictwo - Ochrona przeciwpożarowa w pojazdach szynowych - Część 2: Wymagania dla materiałów i elementów w zakresie właściwości ogniowych.

20. Ustawa z dnia 3 lipca 2002 r. Prawo lotnicze (z późn. zm.), Dz.U.2020.1970 t.j.

21. Rozporządzenie Parlamentu Europejskiego i Rady (WE) nr 300/2008 w zakresie specyfikacji dla krajowych programów kontroli jakości w dziedzinie ochrony lotnictwa cywilnego (z późn. zm.). 